
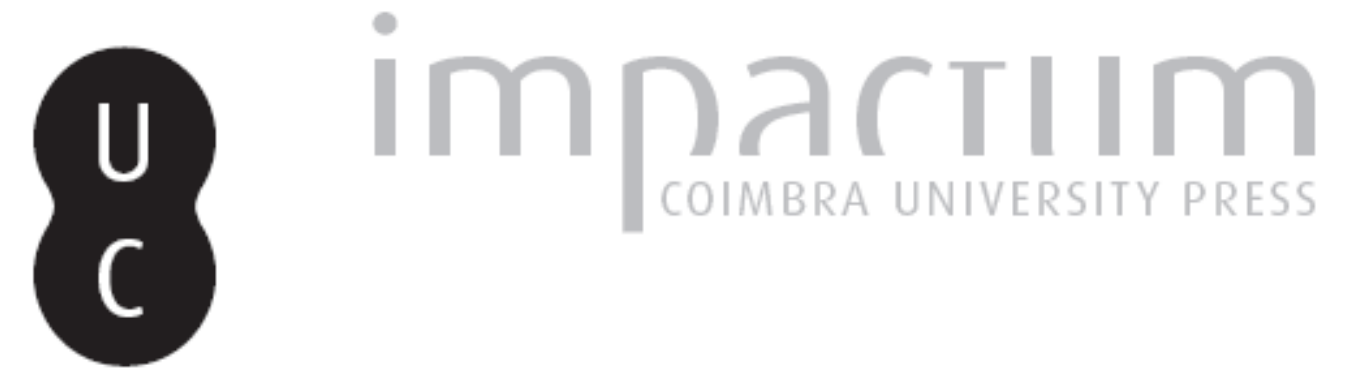

\title{
Escaravelhos Egípcios em Portugal
}

Autor(es): $\quad$ Almeida, Júlia Ferreira de

Publicado por: Centro de História da Universidade de Lisboa

URL persistente:

URI:http://hdl.handle.net/10316.2/23780

DOI:

DOI:http://dx.doi.org/10.14195/0871-9527_19_4

Accessed : $\quad$ 26-Apr-2023 13:55:03

A navegação consulta e descarregamento dos títulos inseridos nas Bibliotecas Digitais UC Digitalis, UC Pombalina e UC Impactum, pressupõem a aceitação plena e sem reservas dos Termos e Condições de Uso destas Bibliotecas Digitais, disponíveis em https://digitalis.uc.pt/pt-pt/termos.

Conforme exposto nos referidos Termos e Condições de Uso, o descarregamento de títulos de acesso restrito requer uma licença válida de autorização devendo o utilizador aceder ao(s) documento(s) a partir de um endereço de IP da instituição detentora da supramencionada licença.

Ao utilizador é apenas permitido o descarregamento para uso pessoal, pelo que o emprego do(s) título(s) descarregado(s) para outro fim, designadamente comercial, carece de autorização do respetivo autor ou editor da obra.

Na medida em que todas as obras da UC Digitalis se encontram protegidas pelo Código do Direito de Autor e Direitos Conexos e demais legislação aplicável, toda a cópia, parcial ou total, deste documento, nos casos em que é legalmente admitida, deverá conter ou fazer-se acompanhar por este aviso.

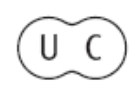



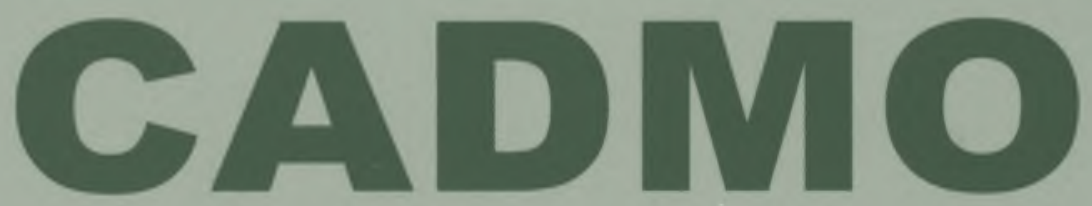

Revista de História Antiga

\author{
Centro de História \\ da Universidade de Lisboa
}

19

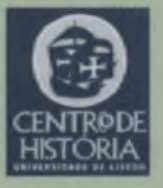

430 =

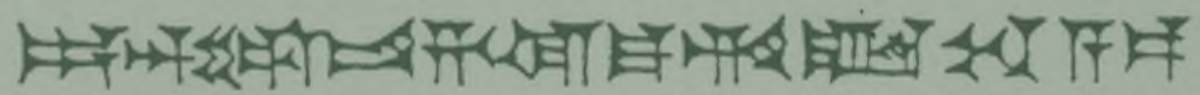

MHNIN AEI $\Delta$ E $\Theta E A ~ \Pi H \Lambda H I A \triangle E \Omega$ 


\title{
ESCARAVELHOS EGÍPCIOS EM PORTUGAL
}

\author{
JÚLIA FERREIRA DE ALMEIDA \\ Universidade de Lisboa \\ julia_almeida@hotmail.com \\ LUÍS MANUEL DE ARAÚJO \\ Universidade de Lisboa \\ luisaraujo@fl.ul.pt
}

\section{Resumo}

Os autores do artigo pretendem divulgar os escaravelhos egípcios ou de tipo egipcizante que se encontram em colecções portuguesas públicas e privadas, incluindo os exemplares que foram achados em escavações arqueológicas realizadas em Portugal em túmulos da Idade do Ferro, além de alguns ainda inéditos, que se encontram em fase de estudo.

Palavras-chave: Escaravelhos; antiguidades egípcias; colecções públicas e privadas em Portugal.

\begin{abstract}
The authors intend to divulge the egyptian or egyptian-like scarabs presently found in public and private portuguese collections, including the ones found in archeological excavations in Portugal, in graves of the Iron Age, besides some unpublished ones, that are still in study.
\end{abstract}

Key words: Scarabs; Egyptian antiquities; public and private collections in Portugal. 


\section{Introdução}

Entre os elementos incontornáveis representativos do antigo Egipto encontramos o escaravelho, um dos animais sagrados mais simbólicos do país das Duas Terras, e que foi usado durante cerca de três mil anos. Atendendo à sua relevância no contexto da civilização egípcia, propomo-nos apresentar neste estudo, ainda que de uma forma necessariamente resumida, os 84 escaravelhos existentes em Portugal: 49 integrados em colecções de museus, seis em colecções privadas, um achado recentemente, e sete cuja localização se desconhece, a que se juntam 21 exemplares pertencentes à colecção Estrada, hoje no Museu Ibérico de Arqueologia e Arte de Abrantes (em processo de instalação), e que ainda estão em fase de estudo, embora um já esteja exposto na igreja de Nossa Senhora do Castelo em Abrantes.

O esforço de síntese que fizemos para um assunto tão complexo obrigou ainda a retirar as imagens de todos os exemplares aqui descritos para não alongar demasiado o artigo. Ainda assim, para cada exemplar constará o tipo de material de que é feito, a sua origem e proveniência (quando forem conhecidas), com a breve descrição do objecto. Posteriormente, numa edição em livro, mais desenvolvida, daremos conta da riqueza deste conjunto nacional, comparando com muitos congéneres de outros museus, e nessa altura se verão as imagens dos objectos (de cima, de lado e em baixo), para mostrar as inscrições que alguns deles exibem, com especial ênfase dada aos que têm versões do capítulo 30 do "Livro dos Mortos".

Antes, porém, contextualizemos a importância do escaravelho na civilização do antigo Egipto. Como é sabido, o Scarabeus sacer era já cultuado desde o IV milénio a. C., atendendo a que foram encontrados vasos com a sua representação em túmulos da Época Pré-Dinástica. A sua relevância poderá estar, desde logo, relacionada com o facto de, em egípcio, escaravelho dizer-se kheperer, prosodicamente semelhante às formas verbais "transformar", "alterar», "tornar-se" e "vir à existência", que em egípcio se dizia kheper ${ }^{(1)}$. Observando a forma como o escaravelho empurrava uma bola de esterco, enterrando-a na areia e emergindo posteriormente desta bola, parecendo "autogerar-se", os Egípcios associaram-no ao aparecimento espontâneo da vida e à imagem do Sol que renasce todos os dias. Neste caso, o Sol assumia o nome de Khepri( ${ }^{(2)}$, "aquele que vem à existência", deus autocriado portanto, normalmente apresentado como um escaravelho, ou como um homem com um escaravelho no lugar da 
cabeça, ou ainda em forma de escaravelho alado, por vezes navegando na barca solar. O fenómeno é-nos relatado por autores clássicos como Plutarco ${ }^{(3)}$. O renascimento do Sol de uma forma cíclica passou igualmente a evocar o renascimento dos defuntos, ficando assim o escaravelho adrede associado ao culto dos mortos, de importância fundamental para o homem que queria ressuscitar, beneficiando da osirificação e da solarização granjeada no Além.

Dada a existência de diversos escaravelhos em museus de todo o mundo, quer em quantidade quer em qualidade, este objecto seria bastante usual. O escaravelho foi efectivamente, desde o final do III milénio a. C. até ao período ptolemaico (305-30 a. C.), quando lentamente vai desaparecendo, o amuleto mais popular no antigo Egipto, muitas vezes usado em anéis, pulseiras, peitorais, colares. Realça-se, no entanto, que ainda que tenham sido produzidos amuletos com a forma de escaravelho durante o Império Antigo, estes têm pouca expressão, não sendo conhecidas representações suas antes da IV dinastia - o que não significa que não tenham existido. Assim sendo, nos escaravelhos datados do Império Médio e do Império Novo que apresentam nomes de reis anteriores (sendo os mais solicitados os poderosos reis da IV dinastia, construtores de pirâmides, Khufu, Khafré e Menkauré), o objectivo seria o de conferir ao objecto maior carga mágica e profiláctica. Salienta-se igualmente Tutmés III (1479-1425 a. C.), o quinto faraó da XVIII dinastia, cujo prenome (ou quarto nome da titulatura régia), Menkheperré, esteve presente nos escaravelhos por muitos séculos, surgindo mesmo em exemplares de Cartago e da Fenícia. No presente estudo encontramos exemplares com a inscrição Menkheperré nos objectos $n .^{\circ s} 6,8,11,17,18,21,22,23$ e 68.

Atendendo à sua conotação amulética, os escaravelhos confeririam sorte aos seus proprietários, sendo usados tanto em vida como no corpo mumificado, cosido às faixas de linho que envolviam o corpo do defunto, ou colocados no próprio corpo. A eficácia do escaravelho enquanto amuleto, geralmente feito de faiança ou de pedras leves, devia-se, por um lado, à sua própria forma e, por outro, às inscrições mágicas inscritas na base.

Para além do seu uso como amuleto de carácter apotropaico, os escaravelhos eram também usados para outros fins, podendo servir para a comemoração de eventos relevantes, servindo como uma espécie de comunicação social dos nossos dias, como disseminadores de informações consideradas relevantes, numa perspectiva de carácter administrativo ou mesmo propagandística, como selos, tendo inscritos 
títulos e nomes de oficiais ou de altos funcionários ${ }^{(4)}$. Os governantes hicsos, em particular, utilizavam o escaravelho para fins sociopolíticos, nomeadamente como uma forma de afirmação de poder, inscrevendo inúmeros deles com os seus nomes e títulos ${ }^{(5)}$.

No que respeita à inscrição nos escaravelhos de nomes identificativos dos reis ${ }^{(6)}$, interlocutores entre os deuses e os homens, chamados, entre outras designações, netjer nefer, "deus bom", aparecem normalmente o prenome e o nome do rei, atendendo ao espaço limitado para a inscrição. No entanto, os belos escaravelhos comemorativos de Amen-hotep III (1390-1353 a. C.), de que falaremos adiante, exibem, dada a sua maior dimensão, os cinco nomes completos da titulatura real ${ }^{(7)}$. A inscrição de nomes reais nos escaravelhos daria protecção aos seus detentores, relacionando o seu proprietário com o intermediário dos deuses, à semelhança do que se passava com os escaravelhos com inscrições de divindades.

A temática da representação de divindades nos escaravelhos ${ }^{(8)}$ surge no Império Médio, ainda que de forma rara, sendo um bom testemunho da religião praticada pelo homem comum no Egipto. Entre as divindades mais representadas destaca-se Amon e, na sua versão sincrética, Amon-Ré, o principal deus cultuado em Tebas-Uaset, capital do Império Novo, estando também frequentemente presentes a deusa Mut, sua esposa, e Khonsu, seu filho, bem como Ptah, Bastet, Bés, Anúbis, Sekhmet, Hathor, Set e $\operatorname{Tot}^{(9)}$. Na fase final do Império Novo (XX dinastia) parece ter havido uma maior procura deste tipo de amuletos com iconografia real e imagens de divindades, aos quais se juntavam os escaravelhos que tinham na base com nomes de particulares e títulos pessoais ${ }^{(10)}$.

Outra temática surge na XVIII dinastia, com escaravelhos contendo fórmulas de boa sorte e preces ou pedidos, que conservam a sua popularidade ainda durante a Época Baixa. Entre as várias temáticas das inscrições dos escaravelhos, é igualmente bastante comum o tema da figura entronizada, como representação do faraó, ou como evocação de divindades perante um altar, ou outros símbolos religiosos, como encontramos, por exemplo, no escaravelho de cornalina patente no Museu Nacional de Arqueologia ${ }^{(11)}$. Quanto à representação de animais nas bases dos escaravelhos, a cobra real (iaret), o antílope, o gato, o falcão, o crocodilo, o leão e o touro eram dos animais que com mais frequência apareciam lá gravados. A partir da Época Baixa, e em especial no período saíta ${ }^{(12)}$, o leão detém a primazia entre os animais representados. A temática do combate de animais que por 
vezes figura nos escaravelhos, consiste, por seu turno, e em regra, no leão, animal solar ligado a Hórus, símbolo do bem, atacando o antílope, animal de Set, amiúde relacionado com o mal, simbolizando no fundo o combate primordial entre o bem (maet) e o mal (isefet).

Pela sua relevância e pela sua presença nas colecções portuguesas, públicas e privadas, apresentamos aqui de forma sumária os escaravelhos funerários, pois se a maior parte dos amuletos podia ser usada em vida e levada para o túmulo, como era por exemplo o signo ankh (vida), o olho de Hórus (udjat) ou o pilar djed, alguns amuletos eram produzidos de facto exclusivamente para o dia do funeral. $\mathrm{O}$ mais importante neste caso era o escaravelho do coração, colocado junto do coração do defunto, órgão central e indispensável para a sua sobrevivência no Além. Preferencialmente feitos de pedras duras, apresentam, em regra, uma versão do capítulo 30 do "Livro dos Mortos", com destaque para a versão reduzida da variante $30 \mathrm{~B}$, inscrita na base ou numa placa feita de outro material que depois se colava à base, existindo exemplares com gravação em folha de ouro(13).

O intuito do escaravelho do coração, com a referida inscrição na base, seria o de influenciar de forma mágica o veredicto do coração relativamente ao carácter moral do defunto. No julgamento final, realizado no maético tribunal de Osíris, e associado ao capítulo 125 do "Livro dos Mortos", o coração do defunto era pesado contra a pena da deusa Maet, um hieróglifo usado para elevados conceitos como a verdade, a justiça, a solidariedade, o bem, enfim, a maet ${ }^{(14)}$, e assim 0 veredicto de justificado (maé-kheru) e puro (ueb), ou condenado, seria ali determinado. Atendendo ao papel relevante da magia no antigo Egipto, o defunto esperava que o apelo do capitulo 30 presente no escaravelho do coração fosse eficaz e sentia-se assim seguro de que, com este amuleto na passagem para a outra vida, passaria com sucesso o julgamento do coração(15).

O texto, no entanto, variava de exemplar para exemplar, de acordo com o espaço disponível para a gravação, o tamanho e qualidade do objecto, bem como com a posição social do defunto ${ }^{(16)}$. Atendendo a que também os escaravelhos do coração eram feitos em série com vista ao seu comércio, o espaço para o nome do defunto, que vinha no início do texto, antecedido pelo título-nome de Osíris ${ }^{(17)}$, era deixado em branco até que aparecesse um comprador. Porém, em vários exemplares de escaravelhos do coração, o nome do defunto não foi inscrito. Encontram-se quatro objectos deste tipo em território nacional, nomeadamente no Museu da Farmácia, no Museu de História 
Natural da Universidade do Porto, no Museu Nacional de Soares dos Reis e na colecção Sam Levy.

Os escaravelhos alados constituem um outro tipo de escaravelho funerário, normalmente feitos de faiança e com as asas abertas e feitas separadamente, podendo apresentar furos para que pudessem ser cosidos nas faixas da múmia. No presente estudo encontramos também quatro exemplares, designadamente nas colecções do Museu Calouste Gulbenkian, Castelo de Vila Viçosa (Fundação da Casa de Bragança), Museu da Farmácia e colecção Sam Levy.

Por seu turno, os escarabóides são representações mais simples do escaravelho, tratando-se especialmente de exemplares do Império Médio (c. 2040-1780 a. C.) e do Segundo Período Intermediário (c. 1780-1560 a. C). Em Portugal, regista-se a presença de um exemplar no Museu de Alenquer e de um outro no Museu de História Natural da Universidade do Porto, que não correspondem, no entanto, às datações acima referidas.

Ainda que não exista qualquer exemplar nas colecções portuguesas, serão aqui evocados, pela sua relevância, os já mencionados escaravelhos comemorativos. Estes objectos foram particularmente apreciados no Império Novo, nomeadamente na XVIII dinastia. Destacam-se, pela sua singularidade, os escaravelhos de Amen-hotep III. No seu reinado, as fábricas reais fizeram uma série de escaraveIhos que se diferenciam de forma notável dos comuns utilizados como selos ou como objectos de adorno pessoal, sendo de maior dimensão. Semelhantes em termos de forma e cor, a sua base, ao invés de ter inscrito o nome e título de um indivíduo ou de um rei, ou de ter um tema de tipo heráldico, apresenta textos de extensão considerável relacionados com eventos da vida do faraó(18). São conhecidas cinco emissões de escaravelhos nestas séries: a primeira foi provavelmente feita pouco após a subida ao trono, estabelecendo a titulatura completa de Amen-hotep III e a da rainha Tié, a "grande esposa real»(19); a segunda terá sido no segundo ano do seu reinado, descrevendo caçadas do rei; no décimo ano do seu reinado, escaravelhos similares assinalam o número de leões que o rei havia abatido desde que subira ao trono; no mesmo ano ainda, o rei juntara ao seu harém a princesa Gilukhepa, filha do rei do Mitanni, assinalando o evento com um anúncio de casamento inscrito na base de escaravelhos; por último, no ano 11 de reinado, uma nova emissão dá conta da construção de um lago de recreio para a rainha Tié, que possivelmente seria em Birket $\mathrm{Habu}^{(20)}$. O escaravelho poderá ter sido enviado para Buhen, na 
Núbia, dado que a inscrição alude ao Hórus de Buhen, como uma espécie de newsletter para dar conta aos sacerdotes e funcionários que aí se encontravam acerca do que se passava na corte. Realce-se ainda que a distribuição destes escaravelhos poderia ser uma forma de desafiar as objecções colocadas pelo facto de Tié não ter sangue real(21).

Apesar da sua notoriedade, a emissão de escaravelhos comemorativos não teve início com Amen-hotep III. Antes dele, o seu avô Amen-hotep II e o seu bisavô Tutmés III haviam já emitido escaraveIhos, com um tamanho regular, para celebrar a colocação de obeliscos, podendo assim ser considerados precursores dos escaravelhos comemorativos de Amen-hotep III (22).

\subsection{Materiais}

Foram utilizados vários materiais para a produção dos escaraveIhos $^{(23)}$. Entre os mais comuns encontram-se a esteatite, que era depois, e em regra, vidrada, o osso e o marfim, utilizados no I milénio quer no Egipto quer na orla do Mediterrâneo. Eram também usadas várias pedras semipreciosas, as quais por vezes não recebiam inscrição uma vez que a própria qualidade do material era já em si mesma mágica, dispensando assim os hekau (inscrições mágicas). Tal é o caso da ametista, utilizada principalmente no Império Médio, da ágata, cujos exemplares conhecidos são sobretudo da Época Baixa e do período ptolemaico, da cornalina, pedra utilizada como elemento de adorno desde a Época Pré-Dinástica que se tornou de uso frequente durante a XVIII dinastia, apresentando ou não decoração na base, o feldspato e o lápis-lazúli, estas duas menos utilizadas. Quanto ao feldspato, foi sobretudo preferido no Império Médio e no Império Novo. Já o lápis-lazúli, usado desde a Época Pré-Dinástica, foi sobretudo utilizado no Império Novo. A raridade deste material levou, no entanto, a que fosse usada a faiança azul escura como imitação.

Há igualmente exemplares feitos de jaspe, nas suas variantes vermelha, verde, negra e castanha. Ainda que sejam conhecidos objectos de adorno e amuletos feitos em jaspe vermelho da Época Pré-Dinástica, esta variedade foi utilizada durante a XVIII dinastia como imitação da cornalina. Já o jaspe verde, cor que simbolizava a renovação e ressurreição, juventude e saúde, foi o preferido para os escaravelhos do coração. Os exemplares feitos de jaspe são contudo raros e o facto de surgirem com mais frequência na segunda metade do 
I milénio deve-se à produção de imitações, essencialmente pela indústria púnica.

O jade foi, por seu turno, um dos materiais menos utilizados no fabrico de escaravelhos, sendo quase todos de épocas tardias e sem base decorada ou inscrita.

São vários os escaravelhos de faiança, matéria preferida para o seu fabrico, bem como de pedra, especialmente basalto, calcário e xisto, particularmente utilizadas nos escaravelhos do coração. Os escaravelhos de esteatite e de faiança, de osso ou marfim, eram os mais solicitados para gravação na base. No entanto, mesmo em pedras muito duras encontramos inscrições, nomeadamente no caso dos escaravelhos do coração.

São também conhecidos exemplares feitos de ouro, ainda que o reduzido número que se conhece possa ser ilusório, pois na altura o ouro não era um metal raro, ao contrário da prata. Os escaravelhos de prata, um metal vindo da Ásia, eram assim invulgares, tal como os de bronze, sendo estes essencialmente utilizados como pesos.

Os escaravelhos em maior número são, no entanto, os de faiança, em tons de azul, azul-esverdeado, verde e branco, representando cerca de um terço dos objectos que integram este estudo.

\subsection{Para lá do Egipto}

Para além do Egipto, onde eles apareceram pela primeira vez, os escaravelhos surgem em outros pontos do Mediterrâneo, tendo sido transportados por comerciantes fenícios ou cartagineses, e, mais tarde, por gregos. Os Fenícios, comerciantes por excelência, terão exportado, entre outros objectos, escaravelhos com inscrições de reis como Tutmés III e Amen-hotep III (com os respectivos prenomes de Menkheperré e Nebmaetré), que por vezes percorriam um longo tra-

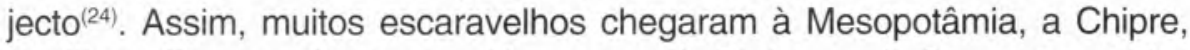
às Ilhas Gregas, Creta, e até mesmo à Etrúria e à Sardenha. A influência fenícia levou à produção de selos em forma de escaravelho na área de Israel, com a inscrição do nome do possuidor do objecto em escrita alfabética. Por seu turno, os Gregos e os Etruscos adoptaram os escaravelhos como forma comum de gemas, inscrevendo nas bases figuras do mundo cultural da Grécia Arcaica ${ }^{(25)}$. Com os escaravelhos "verdadeiros» eram igualmente exportadas cópias, produzidas pelos próprios fenícios. 
A Portugal chegaram alguns escaravelhos, tendo sido encontrados em algumas escavações arqueológicas em contexto da ldade do Ferro, em túmulos do Centro e do Sul do País, estando alguns exemplares actualmente conservados maioritariamente em museus. Encontramos assim exemplares no Museu Arqueológico de Sines, no Museu da Universidade de Coimbra, no Museu de Alenquer, no Museu Municipal de Aljustrel, no Museu Municipal de Almada e no Museu Nacional de Arqueologia. A estes exemplares será preciso acrescentar outros, entre eles um escaravelho de colar, recentemente achado numa intervenção arqueológica no Baixo Alentejo (Beringel, Beja), numa necrópole da I Idade do Ferro.

\section{Escaravelhos em colecções egípcias de Portugal}

\subsection{Museus}

\subsubsection{Solar Condes de Resende}

O núcleo egípcio da Colecção Marciano Azuaga, exposto no Solar Condes de Resende (Canelas), de que é proprietária a Câmara Municipal de Vila Nova de Gaia, integra vinte objectos, entre os quais seis escaravelhos ${ }^{(26)}$.

1 - Escaravelho de faiança esverdeada, com manchas acastanhadas, de origem desconhecida, datando do Império Novo, XVIII ou XIX dinastia (séculos XV-XIII a. C.). Tem a cabeça, clípeos, protórax e élitros diferenciados e patas marcadas em relevo lateral. Exibe na base inscrição hieroglífica gravada, cuja tradução será "Amon-Ré é o senhor», envolta por orla incisa com ligeira fractura. Tem perfuração longitudinal.

2 - Escaravelho de faiança verde, de origem desconhecida, datando talvez do Império Novo. Apresenta a cabeça, clípeos, protórax e élitros diferenciados, e as patas assinaladas em ligeiro relevo lateral. Tem na base uma inscrição gravada, envolvida por orla incisa, com uma ave de longo pescoço curvado, o disco solar e, sobre a ave, o signo men, significando estabilidade e permanência. Tem perfuração longitudinal.

3 - Escaravelho de faiança verde, de origem desconhecida, datando talvez do Império Novo. Mostra bons detalhes anatómicos, com 
a cabeça, clípeos, protórax e élitros diferenciados e patas assinaladas em relevo lateral. $\mathrm{Na}$ base, envolvida por uma orla incisa, apresenta uma figura ajoelhada, parecendo representar o deus Heh, tendo em cada mão um ramo de palmeira rematado por uma flor de lótus. Em cima está uma barca com o disco $\operatorname{solar}^{(27)}$ e em baixo o signo neb. Tem perfuração longitudinal.

4 - Escaravelho de faiança verde, de origem desconhecida, datando talvez do Império Novo. Tem detalhes anatómicos bastante erodidos: cabeça, protórax e élitros diferenciados, patas marcadas lateralmente. Apresenta uma inscrição gravada na base, envolvida por orla incisa e parcialmente erodida. Tem perfuração longitudinal.

5 - Escaravelho de esteatite castanha, de origem desconhecida, datando talvez do Império Novo. Tem a cabeça, clípeos, protórax e élitros diferenciados, com as patas marcadas lateralmente. Apresenta decoração gravada na base, envolvida por orla incisa parcialmente erodida, disposta em três registos separados por traços incisos: em cima, uma ave de longo pescoço virado para trás com um disco solar à direita; ao meio, vários signos hieroglíficos que incluem duas serpentes viradas à esquerda; em baixo o desenho de um escaravelho ladeado por duas plumas que parecem ser a estilização das penas maéticas. Tem perfuração longitudinal.

6 - Escaravelho de esteatite castanha, de origem desconhecida, datando talvez do Império Novo. Tem a cabeça, clípeos, protórax e élitros diferenciados, com as patas marcadas em relevo lateral. Tem decoração gravada na base, envolvida por orla incisa parcialmente erodida: tem ao centro uma cartela com o nome de Menkheperré, apoiada no signo nub (ouro) e encimada por duas plumas que procuram imitar o signo maético. A cartela é ladeada por duas serpentes com cabeças viradas para fora, tendo sobre as cabeças algo sugerindo o disco solar ou plumas. Tem perfuração longitudinal.

\subsubsection{Castelo de Vila Viçosa (Fundação Casa de Bragança)}

7 - Dos oito objectos que compõem a colecção egípcia do rei D. Luís (1838-1889), e que hoje se conservam no Paço Ducal de Vila Viçosa (Fundação da Casa de Bragança) ${ }^{(28)}$, um deles é um escaraveIho alado, em madeira pintada, com origem e datação desconhecidas. Tem perfuração para ser cosido às faixas de linho da múmia. Está pintado em azul e dourado, evocando assim duas cores com um grande 
significado mágico e ideológico, nomeadamente o lápis-lazúli e o ouro. Apresenta detalhes anatómicos em ligeiro relevo, tendo duas asas de abutre abertas.

\subsubsection{Museu Arqueológico de Sines}

Entre as peças exibidas no Museu Arqueológico de Sines encontra-se um escaravelho de marfim de pequenas dimensões, encontrado em Portugal, em 1966, numa sepultura na Herdade do Gaio, próximo de Sines ${ }^{(29)}$.

8 - Trata-se de um sinete de marfim gravado em relevo na parte exterior com a forma de escaravelho, apresentando a cabeça, clípeos, protórax e élitros diferenciados. Na parte posterior tem uma inscrição hieroglífica, com vestígios de cor verde azulada, em que se representa o olho de Hórus (udjat), a deusa Taueret, e um nome encartelado, possivelmente o de Menkheperré. Este amuleto pertencia a um anel e estava engastado em estojo elipsoidal de prata com terminais tubulares, de onde prendia $o$ anel. Tem perfuração longitudinal para suspensão.

\subsubsection{Museu Calouste Gulbenkian}

A colecção egípcia do Museu Calouste Gulbenkian integra dois escaravelhos, um dos quais guardado nas reservas ${ }^{(30)}$ :

9 - Escaravelho alado de faiança, datando da Época Baixa, XXVI dinastia (664-525 a. C.). É proveniente da colecção MacGregor, tendo sido adquirido através de Howard Carter e incorporada no acervo em 1922. As asas, com apontamentos verdes azuis e pretos e de dimensões diferentes, são feitas separadamente e, tal como o próprio escaravelho, têm furos para que pudessem ser cosidas nas ligaduras da múmia. O corpo do escaravelho é, por seu turno, preto, apresentando a cabeça, clípeos, protórax e élitros bem assinalados, e as patas indicadas em relevo.

10 - Escaravelho de faiança azul-turquesa (está nas reservas do Museu). Data da Época Baixa, talvez da XXVI dinastia, tendo sido adquirido por Calouste Gulbenkian a Howard Carter e incorporado na colecção em 1925, sem nunca ter sido exposto, apesar da sua beleza. Apresenta a cabeça com clípeos sumariamente tratados, protórax liso, 
élitros separados e marcados por traços verticais incisos. As patas assentam na base ovalada, que apresenta seis perfurações para permitir a sua cosedura nas ligaduras da múmia.

\subsubsection{Museu Condes de Castro Guimarães}

Das seis peças que constituem a pequena colecção egípcia do Museu, dois deles são escaravelhos ${ }^{(31)}$.

11 - Escaravelho de faiança verde, de origem desconhecida, datando do Império Novo (?). É de pequenas dimensões, com a carapaça numa tonalidade mais clara, a cabeça e clípeos bem assinalados, protórax e élitros diferenciados, e as patas assinaladas lateralmente. O corpo assenta em base ovalada, tendo inscrito o nome de Menkheperré, com o signo kheper alado, delimitado por uma orla incisa. Tem perfuração longitudinal para suspensão.

12 - Escaravelho em faiança verde escura, de origem desconhecida, datando da Época Baixa ou da Época Greco-Romana (séculos VII-III a. C.). Apresenta detalhes anatómicos sumariamente tratados, com a cabeça e os clípeos esquematizados, sendo possível distinguir a separação do protórax e dos élitros, estando as patas indicadas lateralmente por leves traços incisos. A base ovalada apresenta uma fruste gravação representando uma ave (eventualmente um falcão). Tem perfuração longitudinal para suspensão.

\subsubsection{Museu da Farmácia}

A colecção egípcia do Museu da Farmácia, cujo catálogo referente aos objectos pré-clássicos foi recentemente editado, integra três escaravelhos $^{(32):}$

13 - Escaravelho alado de faiança azul brilhante, de origem e proveniência desconhecidas, datando da Época Baixa (664-332 a. C.) ou do período ptolemaico (332-30 a. C.). Apresenta clípeos sumariamente indicados, olhos assinalados por dois pontos negros, protórax pouco definido, élitros separados por três traços verticais incisos. O corpo do escaravelho é delimitado por uma orla incisa, não estando assinaladas as patas. As asas, simétricas, são feitas separadamente, alterando a cor azul com o preto. Tem perfuração no corpo e nas asas do escaravelho para cosedura às faixas de linho que envolviam a múmia. 
14 - Escaravelho do coração de pedra escura, possivelmente basalto, de origem desconhecida, tendo sido adquirido em 2000 a Oliver Forge e Brandon Lynch. Data de 640-600 a. C. (inícios da Época Baixa). Cabeça e clípeos marcados, protórax e élitros diferenciados, apresentando o protórax um pontilhado e os élitros várias linhas incisas verticais. $\mathrm{O}$ corpo assenta em base ovalada. Apresenta inscrito na base o capítulo 30 do "Livro dos Mortos", e tem furo no cimo da cabeça.

15 - Escaravelho de pequenas dimensões em faiança verde, de origem e proveniência desconhecidas, datando da Época Baixa (664-332 a. C.). Coleóptero com cabeça e clípeos marcados, protórax liso, apresentando os élitros linhas incisas verticais. Ainda que as patas não se encontrem marcadas lateralmente, o corpo assenta numa base lisa e irregular, que parece sugerir o formato do apoio do corpo nas patas.

\subsubsection{Museu da Universidade de Coimbra}

16 - Integra um escaravelho de massa com origem provável de Náucratis ${ }^{(33)}$, datando possivelmente da segunda metade do século VII a. C. (Época Baixa). Foi encontrado a 24 de Março de 1925, numa sepultura da necrópole pré-romana do Olival do Senhor dos Mártires, em Alcácer do Sal, durante as escavações conduzidas por Virgílio Correia. Nessa altura foi considerado um dos mais antigos do seu género encontrados na Península Ibérica e o primeiro referenciado em Portugal, susceptível de uma datação segura. Apresenta inscrito o nome de Hórus de Psametek I (Hórus grande de coração", Hor-aá-ib), bem como, possivelmente, a deusa Sekhmet segurando o ceptro uadj numa das mãos e o signo ankh na outra, e o sol alado. Ingrid Gamer-Wallert integra-o na sua lista de escaravelhos encontrados em Portugal(34).

\subsubsection{Museu de Alenquer (Museu Hipólito Cabaço)}

Inclui dois sinetes de anel, encontrados em locais diferentes dos níveis inferiores da jazida romana do Porto do Sabugueiro, Muge, sendo um deles de tipo escarabóide e o outro um escaravelho, encontrados em Portugal em contexto da Idade do Ferro ${ }^{(35)}$. Como refere Maria Amélia Horta Pereira num estudo sobre os objectos, a autenticidade foi comprovada por peritagem directa no Departamento de Antiguidades Egípcias do Museu Britânico. Estas duas peças podem 
datar-se entre o século $X$ e o século VI a. C, sendo possivelmente cópias fenícias de originais egípcios.

17 - Escarabóide em pasta macia, cor de marfim, envernizada de branco, em bom estado de conservação. Apresenta no dorso a cabeça pintada de negro e na base plana uma inscrição: no lado esquerdo dois udjat hóricos, estando o inferior sublinhado, e do lado direito uma cartela envolvendo o nome de Menkheperré. Tem perfuração longitudinal para suspensão ${ }^{(36)}$.

18 - Escaravelho em pasta cor de marfim, envernizada de negro, em bom estado de conservação. Tem o protórax e élitros marcados, lisos, com base plana, contendo a inscrição Menkheperré encartelada, no lado direito. A divindade que se apresenta no lado esquerdo de pé, virada à direita, poderá ser Set, mas também Sobek ou Taueret. Ingrid Gamer-Wallert, na descrição que faz deste objecto, sugere que a personagem que consta no lado esquerdo da base seja o deus Set, o que parece ser improvável na época de Tutmés III, sendo, no entanto, já aceitável para o período ramséssida ${ }^{(37)}$. Tem perfuração longitudinal para suspensão.

\subsubsection{Museu de História Natural da Universidade do Porto}

O Museu de História Natural da Universidade do Porto conserva um exemplar de tipo escarabóide, e onze exemplares de escaraveIhos, dois dos quais escaravelhos do coração, apresentando um deles uma versão do capítulo 30 B do "Livro dos Mortos". Estes objectos fazem parte do lote de antiguidades oferecidas pela Alemanha a Portugal em $1926^{(38)}$.

19 - Escarabóide de esteatite esverdeada vidrada, de origem desconhecida, sendo proveniente da colecção Minutoli e datando do Segundo Período Intermediário ou início da XVIII dinastia, séculos XVI-XV a. C. Tem a carapaça lisa, sendo decorado lateralmente com estrias incisas. Exibe na base uma decoração estilizada simétrica de temática floral ao centro e com serpentes em cima e em baixo. Tem perfuração longitudinal para suspensão.

20 - Escaravelho de esteatite esverdeada vidrada, de origem desconhecida, sendo proveniente do espólio do Dr. Parthey, adquirido em 1877 e datando do Império Novo. Tem cabeça e clípeos esquematizados, protórax e élitros não diferenciados. A base, que tem uma orla incisa, apresenta uma imagem do signo neb (posse) com estrias 
oblíquas, tendo sobre ele ao centro o signo sa (protecção) ladeado por dois signos uadj (rejuvenescimento) e nas extremidades por elementos florais. Tem perfuração longitudinal para suspensão.

21 - Escaravelho de faiança azulada, de origem desconhecida, sendo proveniente da colecção Lepsius e datando do Império Novo, XIX-XX dinastias, séculos XII-X a. C. Cabeça e clípeos marcados, o protórax e os élitros diferenciados, com patas marcadas lateralmente. $\mathrm{Na}$ base, envolvida por uma orla incisa, apresenta uma inscrição hieroglífica com o nome de Menkheperré. Tem perfuração longitudinal para suspensão.

22 - Escaravelho de esteatite esverdeada, de origem desconhecida, sendo proveniente da colecção Minutoli e datando do Império Novo. Tem cabeça mas não tem detalhes no dorso, as patas estão marcadas lateralmente de forma esquemática. Na base, envolvida por uma orla incisa, apresenta uma inscrição hieroglífica com o nome de Menkheperré e outros signos hieroglíicos de leitura difícil, parecendo, no entanto, tratar-se do nome encartelado de Menkheperré em cartela antecedido pelo título de netjer nefer (deus beneficente) e neb-taui (senhor das Duas Terras) e seguido por um grupo de signos que poderá ser meri Amon (amado de Amon) ou o nome do deus tebano seguido por um olho hórico udjat estilizado. Tem perfuração longitudinal para suspensão.

23 - Escaravelho de faiança esverdeada, de origem desconhecida, sendo proveniente da colecção Pallin, adquirida em 1859, e datando do Império Novo ou posterior. Está ligeiramente fracturado, com a cabeça e clípeos marcados, protórax e élitros diferenciados, patas marcadas lateralmente. Apresenta na base envolvida por uma orla incisa e parcialmente desaparecida uma inscrição hieroglífica com o nome de Menkheperré ladeado por duas serpentes estilizadas. Tem perfuração longitudinal para suspensão.

24 - Escaravelho de faiança acastanhada, de origem desconhecida, sendo proveniente da colecção Minutoli e datando do Império Novo. Apresenta detalhes na cabeça, clípeos marcados, protórax e élitros diferenciados, patas marcadas lateralmente. Apresenta na base decoração estriada.

25 - Escaravelho de pedra, de origem desconhecida, sendo proveniente da colecção Passalacqua e datando do Império Novo. Trata-se de um exemplar de tipo naturalista com detalhes na cabeça, clípeos marcados, protórax e élitros diferenciados, patas marcadas lateralmente. A base é lisa. 
26 - Escaravelho de faiança esverdeada, com revestimento vidrado parcialmente desaparecido, de origem desconhecida, tendo sido adquirido pelo Dr. Stern ao cônsul von Dütilh em 1881, e datando do Império Novo, XVIII dinastia. Apresenta a cabeça esquematizada, protórax e élitros diferenciados e patas marcadas lateralmente. $\mathrm{Na}$ base lisa consta o nome de Nebmaetré, e que significa "O deus Ré é senhor de Maet". Tem perfuração longitudinal para suspensão.

27 - Escaravelho de quartzo, de origem desconhecida, sendo proveniente da colecção Minutoli e datando do Império Novo. Tem a cabeça esquematizada, protórax e élitros diferenciados e patas marcadas lateralmente. A base é lisa. Tem perfuração longitudinal para suspensão.

28 - Escaravelho do coração de diabase esverdeada, de origem desconhecida, sendo proveniente da colecção Passalacqua e datando do Império Novo. Tem a cabeça com os clípeos marcados, protórax e élitros diferenciados com estrias de linhas duplas. Apresenta patas marcadas lateralmente e base lisa.

29 - Escaravelho do coração de basalto, com placas de xisto na base, originário de Mênfis e proveniente da colecção Passalacqua. Data do Império Novo, XVIII-XIX dinastias (séculos XV-XIII a. C). Tem a cabeça e clípeos marcados, protórax e élitros diferenciados, patas marcadas lateralmente. A base é formada por três placas de xisto unidas que contêm uma inscrição hieroglífica em sete linhas horizontais com uma versão do capítulo 30 do "Livro dos Mortos". O espaço para a gravação do nome do defunto não foi preenchido.

30 - Escaravelho de faiança azul-turquesa, de origem desconhecida, proveniente da colecção Minutoli e datando da Época Baixa. Tem a cabeça e os clípeos marcados, protórax e élitros diferenciados. A base é lisa e apresenta furos laterais para adaptação das asas (já desaparecidas).

\subsubsection{Museu Municipal de Aljustrel}

31 - Na sua colecção integra um escaravelho encontrado numa intervenção de emergência, levada a cabo por técnicos da Extensão Territorial do Instituto Português de Arqueologia de Castro Verde, entre eles a arqueóloga Manuela de Deus, na necrópole da Idade do Ferro de Corte Margarida, Aljustrel, com uma cronologia proposta em torno do século VI a. C. para as duas sepulturas intervencionadas. Este 
objecto foi encontrado na sepultura 2, não se conhecendo por agora o material de que é feito. Tem perfuração longitudinal para suspensão, presumindo-se que tenha sido utilizado como elemento decorativo num colar. Apresenta o protórax e élitros diferenciados, com várias marcas de erosão. Tem inscrição na base, onde se pode ler o nome do rei Padibastet, da XXIII dinastia, não sendo possível identificar se se trata do I, II, ou III com este nome ${ }^{(39)}$.

\subsubsection{Museu Municipal de Almada}

32 - Inclui um escaravelho de faiança, de origem desconhecida, datando da Época Baixa, dinastias XXVI-XXX (séculos VII-V a. C.). Trata-se de um elemento de anel quase completo, encontrado na Quinta do Almaraz, num contexto do século VII a. C. ${ }^{(40)}$ Apresenta inscrição na base, onde se pode identificar um signo representando um touro em posição de marcha e outros dois signos indefinidos. O signo do touro tem a leitura ka, com o significado objectivo de touro ou o significado genérico de gado. No que respeita aos outros signos, estão bastante erodidos, pelo que são de difícil e dúbia identificação. O que está em cima do touro parece ser o hieróglifo $n$, podendo ser a forma abreviada de neb, com o significado de senhor, ou o signo "poderoso" (nakht), ainda que esta seja uma hipótese menos plausível. Quanto ao signo gravado à frente do touro, no canto inferior direito, parece ser o signo para papiro, com a leitura de uadj. As imagens gravadas na base do escaravelho parecem, então, constituir signos isolados que se associam para preencher o espaço para inscrição ou para decorar a base, como parece ser o caso, o que é típico da época em que se pode situar o escaravelho.

\subsubsection{Museu Nacional de Arquelogia}

Entre os diversos objectos da colecção egípcia do Museu Nacional de Arqueologia, encontram-se doze escaravelhos expostos ${ }^{(41)}$, bem como quatro escaravelhos nas reservas, achados em Portugal em túmulos da Idade do Ferro.

33 - Escaravelho-sinete de granito (riólito), de origem e proveniência desconhecidas, datando do Império Novo ou ulterior, séculos XVI-VIII a. C. Objecto compósito formado por um falcão de asas recoIhidas pousado sobre um escaravelho, que tem na base uma inscrição 
hieroglífica delimitada por orla, cuja leitura poderá ser «Hórus, senhor de paz e sucesso".

34 - Escaravelho de serpentina castanha, de origem e proveniência desconhecidas, datando do Império Novo ou ulterior, séculos XVI-VIII a. C. Apresenta excelente feitura, com cabeça e olhos em detalhe, clípeos marcados mas parcialmente destruídos devido à fractura do objecto, protórax liso e separado dos élitros marcados por linhas incisas verticais. Patas marcadas lateralmente, com os ombros indicados. A base é lisa.

35 - Escaravelho de faiança esverdeada, de origem e proveniência desconhecidas, datando do Império Novo ou ulterior, séculos XVI-VIII a. C. Tem a cabeça e os clípeos marcados, protórax e élitros diferenciados, lisos. É perfurado longitudinalmente para adaptação a um anel e provável uso como sinete. Exibe uma inscrição na base, já erodida, que está envolvida por uma orla em relevo que traduzida será "Amon-Ré é o senhor».

36 - Escaravelho de marfim, de origem e proveniência desconhecidas, datando da Época Baixa ou período ptolemaico, séculos VII-III a. C. Tem a cabeça e os clípeos esquematicamente marcados, protórax e élitros diferenciados com traço duplo, patas sugeridas lateralmente. Apresenta inscrição na base e tem perfuração longitudinal para adaptação a um anel.

37 - Escaravelho de marfim, de origem e proveniência desconhecidas, datando da Época Baixa ou do período ptolemaico (séculos VII-III a. C.). Exemplar em bom estado de conservação, com cabeça e clípeos marcados, patas marcadas lateralmente, protórax e élitros diferenciados. Tem perfuração longitudinal para adaptação a um anel e provável uso como sinete e apresenta inscrição na base, em três registos diferentes, separados por traços duplos incisos: no superior um signo neb, no centro um pequeno texto com uma possível leitura de "toda a terra para o senhor de tudo", e na base, o signo djed ladeado por duas coroas vermelhas do Baixo Egipto.

38 - Escaravelho de marfim, de origem e proveniência desconhecidas, datando da Época Baixa ou do período ptolemaico (séculos VII-III a. C.). Tem a cabeça e os clípeos marcados, protórax e élitros não diferenciados, apresentando inscrição na base, delimitada por orla incisa.

39 - Escaravelho de faiança azul-turquesa, de origem e proveniência desconhecidas, datando da Época Baixa ou do período ptolemaico (séculos VII-III a. C.). Tem a cabeça sumariamente indicada, sem clípeos e sem detalhes no dorso, patas estilizadas em incisões 
laterais, tendo inscrição na base. A decoração da base, sem orla envolvente, apresenta um animal com longos cornos lançados para trás, parecendo tratar-se de um antílope, em posição de marcha, virado à esquerda, tendo atrás o disco solar.

40 - Escaravelho de serpentina verde, de origem e proveniência desconhecidas, datando da Época Baixa ou do período ptolemaico (séculos VII-III a. C.). Apresenta a cabeça e os clípeos marcados, protórax e élitros diferenciados. Tem perfuração longitudinal para suspensão.

41 - Escaravelho de jade, de origem e proveniência desconhecidas, datando do período ptolemaico (séculos IV-I a. C.). Tem a cabeça e os clípeos marcados, protórax e élitros diferenciados, patas marcadas lateralmente e base lisa.

42 - Escaravelho de cornalina, de origem e proveniência desconhecidas, datando do período ptolemaico (séculos IV-I a. C.). Está fracturado, com a cabeça e clípeos esquematicamente marcados e dorso sem detalhes. Tem perfuração longitudinal e base com decoração, que apresenta uma figura entronizada, virada à esquerda, segurando um ceptro cuja parte superior desapareceu devido à fractura do objecto. A figura está frente a um altar de pé alto, com dois remates sobrepostos. O conjunto assenta sobre o signo neb.

43 - Escaravelho de faiança avermelhada, de origem e proveniência desconhecidas, datando do período ptolemaico (séculos IV-I a. C.). Exemplar com várias fracturas, com a cabeça e clípeos marcados, protórax e élitros diferenciados, patas em relevo lateral. A base, de contornos irregulares devido às várias fracturas, apresenta inscritas várias letras gregas sem ordem aparente e sem leitura coerente.

44 - Escaravelho, talvez de jaspe, de origem e proveniência desconhecidas, datando do período ptolemaico (séculos IV-I a. C.). Tem cabeça e clípeos marcados, protórax e élitros diferenciados, patas assinaladas lateralmente, com decoração na base, com perfuração na base para adaptação a um anel e provável uso como sinete. O tema inscrito na base do escaravelho, de um touro atacado por dois leões assente no signo neb, aproxima-se das representações da Mesopotâmia, onde as cenas de leões atacando touros remontam à época de Uruk IV e Djemdet Nasr (c. 3200-2800 a. C.). Não tendo sido produzido no Egipto, a temática associa-o às produções fenícias ou às da Sardenha, que entre o século V e o III a. C., sob o domínio cartaginês, deram origem a exemplares em estilo grego ou helenizante e em estilo fenício. 
Tal como já foi referido, existem ainda quatro escaravelhos que fazem parte das reservas:

45 - Escaravelho de quartzo castanho-escuro, de pequenas dimensões, em muito bom estado de conservação, achado na necrópole da Azinhaga do Senhor dos Mártires, Alcácer do Sal, proveniente de um aglomerado de cinzas que cobria uma sepultura de incineração cavada na rocha. De possível origem de Náucratis, data da II Idade do Ferro, século IV a. C., com base em paralelos. Apresenta a cabeça e clípeos bem marcados, patas sugeridas lateralmente, protórax liso, separado dos élitros lisos divididos por uma linha vertical incisa. Tem perfuração longitudinal para suspensão. Tem uma inscrição na base com várias figuras: ao centro apresenta um felino, sentado sobre o símbolo neb, ladeado, à esquerda, por uma cobra em posição erecta ostentando a coroa do Alto Egipto, e à direita o caule de um papiro encimado pela respectiva flor que parece erguer-se a partir de uma das patas anteriores da leoa ${ }^{(42)}$.

46 - Escaravelho de espinela com uma pequena percentagem de piroxena, de pequenas dimensões, achado na sepultura $F 11$ da necrópole da Azinhaga do Senhor dos Mártires, Alcácer do Sal. De possível origem de Náucratis, data da II Idade do Ferro (séculos V-IV a. C.), com base em paralelos. Apresenta cabeça e clípeos bem marcados, com patas sugeridas lateralmente, protórax liso e demarcado, élitros lisos divididos por três linhas verticais incisas. Tem perfuração longitudinal para suspensão e inscrição na base, estando lá representados uma esfinge alada e a pena da maet, simbolizando, respectivamente, o poder real e a verdade, justiça, ordem universal.

47 - Escaravelho de material brando de cor verde acinzentada, de pequenas dimensões, achado na sepultura 22/80 da necrópole da Azinhaga do Senhor dos Mártires, Alcácer do Sal. Data da II Idade do Ferro (séculos V-IV a. C.), com base em paralelos. Apresenta cabeça e clípeos bem marcados, com patas sugeridas lateralmente. O objecto apresenta pouca definição no que respeita ao protórax e élitros, podendo-se, no entanto, identificar o protórax liso e os élitros divididos por uma linha vertical (élitro direito em pior estado, apresentando alguns traços incisos). Tem perfuração longitudinal para suspensão e inscrição na base, estando representadas duas figuras antropomórficas com joelhos ligeiramente flectidos e os braços erguidos para uma palmeira(43).

48 - Escaravelho de ágata de cor escura listrada a branco, em muito bom estado de conservação. Possivelmente originário de Náucratis, 
é proveniente de uma área com terras superficiais remexidas, perto da sepultura $F 11$ da necrópole da Azinhaga do Senhor dos Mártires, Alcácer do Sal. Data da II Idade do Ferro (séculos V-IV a. C.), com base em paralelos. Apresenta a cabeça e clípeos bem marcados, patas sugeridas lateralmente, protórax liso e élitros lisos, separados por uma linha vertical incisa. Tem perfuração longitudinal para suspensão, e na base, incompleta, restam vestígios da inscrição: no canto superior, o sol alado e um pequeno disco sobreposto a um crescente de pontas voltadas para cima; no centro, uma cabeça, semelhante à de um falcão, de uma figura a que duas outras figuras, uma de cada lado, prestam homenagem. Em baixo, nota-se ainda vestígios do símbolo neb.

\subsubsection{Museu Nacional de Soares dos Reis}

49 - Dos oito objectos que constituem o acervo de antiguidades egípcias do Museu, e que são propriedade da Câmara Municipal do Porto, um deles é um escaravelho do coração, de basalto, que durante alguns anos esteve exposto no Museu Romântico do Porto. É de origem desconhecida, datando do Império Novo, XVIII-XIX dinastias (séculos XV-XIII a. C.). Apresenta cabeça, olhos e clípeos feitos em detalhe. O protórax e os élitros diferenciados são lisos e delimitados por traços duplos incisos, estando as patas assinaladas em relevo lateral. A base ovalada apresenta uma inscrição hieroglífica com a variante B, em versão reduzida, do capítulo 30 do "Livro dos Mortos", em sete linhas horizontais separadas entre si por traços incisos. O nome do defunto não está, no entanto, inscrito(44).

\subsection{Colecções privadas}

\subsubsection{Colecção Fernando Freitas Simões}

50 - Dos vinte objectos que constituem a colecção um deles é um escaravelho de faiança azul, de origem desconhecida, datando da Época Baixa. Apresenta clípeos estilizados, protórax e élitros marcados por incisões, não estando as patas assinaladas. Tem cinco furos (um à frente e dois de cada lado) podendo assim ser cosido nas faixas de linho da múmia ou receber asas. Tem a base lisa ${ }^{(45)}$. 


\subsubsection{Colecção Luís Manuel de Araújo}

51 - Escaravelho de faiança verde, com brilho vítreo no revestimento e ligeiras fracturas laterais, de origem desconhecida e datando do Império $\mathrm{Novo}^{(46)}$. Apresenta a cabeça com clípeos sumariamente marcados, protórax e élitros diferenciados por incisões e patas em relevo lateral. Tem perfuração longitudinal para provável adaptação a um anel ou a um colar. Apresenta base com orla incisa parcialmente danificada e inscrição com vários signos, podendo ler-se o nome de Amon, e as formas mer e neb.

\subsubsection{Colecção Mário Jorge Barroca}

52 - A colecção integra um escaravelho de pequenas dimensões em faiança azul-esverdeada, de origem desconhecida, datando da Época Baixa (séculos VII-IV a. C.). O exemplar apresenta cabeça e clípeos marcados, com maior definição do lado direito, protórax e élitros diferenciados e lisos, assente em base ovalada, com patas sugeridas lateralmente. A base, delimitada por orla incisa parcialmente erodida, tem inscritos signos hieroglíficos, mostrando um falcão coroado, aparentemente com a coroa dupla do Alto e do Baixo Egipto, sobre um signo neb que alude à totalidade e à posse, ladeado por elementos decorativos que poderão ser duas serpentes de pescoço tumefacto, a serpente sagrada iaret (uraeus). Foi adquirido pelo proprietário num antiquário de Londres ${ }^{(47)}$.

\subsubsection{Colecção Sam Levy}

Na colecção Sam Levy, composta por 34 objectos, existem três escaravelhos, sendo um deles um escaravelho do coração e outro um escaravelho alado ${ }^{(48)}$.

53 - Escaravelho do coração de basalto, de origem desconhecida, datando do Império Novo (séculos XV-XIII a. C.). É um exemplar de grandes dimensões em excelente estado de conservação, com a cabeça, os olhos e os clípeos feitos com detalhe, protórax e élitros diferenciados lisos e delimitados por traços incisos, estando as patas assinaladas lateralmente. Um traço inciso maior separa o corpo do escaravelho da base ovalada, a qual apresenta uma versão do capítulo 30 do "Livro dos Mortos", a variante 30 B em versão reduzida, com o texto hieroglífico gravado em nove linhas horizontais separadas entre 
si por traços duplos incisos, lendo-se da esquerda para a direita (o final do texto não está, no entanto, presente).

54 - Escaravelho alado de faiança verde, de pequenas dimensões, de origem desconhecida, datando da Época Baixa (séculos VII-IV a. C.). Tem cabeça indefinida mas protórax e élitros estriados reconhecíveis. Tem orifício para suspensão.

55 - Escaravelho de serpentina verde, de origem desconhecida, datando da Época Baixa ou do período ptolemaico (séculos VII-I a. C.). Apresenta vários traços incisos e esquemáticos sugerindo a anatomia do escaravelho, e a base é lisa.

\subsection{Descobertas recentes}

56 - Foi recentemente descoberto um escaravelho de colar numa intervenção arqueológica no Baixo Alentejo (Palhais, Beringel, Beja), dirigida por Filipe Santos, numa necrópole da I Idade do Ferro, possivelmente do século VII ou VI a. C. Este novo escaravelho será talvez do Império Novo ou ulterior (séculos XVI-VIII a.C.), na medida em que a base, com uma orla bastante erodida, apresenta uma inscrição na qual se pode identificar o nome de Amon-Ré, divindade sincrética tebana. Esta referência sugere que o escaravelho terá sido produzido num período anterior à emergência da XXVI dinastia saíta (664-525 a. C.), com centro político no Norte, em Sais, uma das sedes de culto a Neit, sendo Amon eclipsado por outras divindades. O objecto, feito de pedra branda, tem a cabeça e os clípeos marcados, patas sugeridas lateralmente, protórax liso e élitros lisos separados por uma linha incisa, apresentando tanto o protórax como os élitros algumas marcas. Tem perfuração longitudinal para suspensão ${ }^{(49)}$.

\subsection{Objectos não localizados}

Uma última referência ao facto de termos encontrado notícia, na monografia, já um tanto antiga, de Ingrid Gamer-Wallert, Ägyptische und ägyptisierende Funde von der Iberischen Halbinsel (1978), de três outros escaravelhos encontrados em Portugal, não tendo, no entanto, sido possível até ao momento localizá-los. Apresentamos, ainda assim, os três objectos descritos pela investigadora alemã:

57 - Escaravelho encontrado em 1970, na necrópole do Monte de A-do-Mealha-Nova (Ourique), da I Idade do Ferro, por uma equipa 
de arqueólogos integrando Maria Manuela Alves Dias, Caetano de Mello Beirão e Luís Coelho. De acordo com a descrição por eles feita, trata-se de um escaravelho engastado num anel em metal, numa moldura giratória, ovalóide, formada por três finas cintas filiformes, feito de faiança de coloração verde quase uniforme e de brilho acetinado, com o protórax e os élitros marcados. $\mathrm{Na}$ face do sinete está inscrito o nome do rei Padibastet, fundador da XXIII dinastia (Terceiro Período Intermediário), que reinou de 818-793 a. C. Segundo os referidos arqueólogos, a partir de uma informação de Ingrid Gamer-Wallert, será provavelmente oriundo de Náucratis ${ }^{(50)}$. Este objecto fez parte da exposição organizada em 1980 pelo na altura chamado Museu Nacional de Arqueologia e Etnologia (hoje Museu Nacional de Arqueologia), subordinada ao tema "A I Idade do Ferro no Sul de Portugal. Epigrafia e Cultura", altura em que o objecto estava na posse de Luís Coelho, de acordo com informação do catálogo dessa exposição.

58 - Escaravelho encontrado por Caetano de Mello Beirão na necrópole de Fonte Santa (Ourique), feito em pasta cerâmica de cor marfim, com cabeça, protórax e élitros esboçados e inscrição na base. $\mathrm{Na}$ necrópole foi ainda encontrado um anel com engaste rotativo e escaravelho, feito de prata e pasta cerâmica (59); um anel com escaravelho rotativo (60); e fragmentos de anel com escaravelho rotativo (61), todos eles igualmente presentes na exposição acima referida do então Museu Nacional de Arqueologia e Etnologia.

62 - Ingrid Gamer-Wallert refere-se ainda a um escaravelho encontrado em Odemira, feito de pasta verde e com inscrição na base ${ }^{(51)}$.

Realça-se ainda que, na consulta ao catálogo da exposição do Museu Nacional de Arqueologia e Etnologia, foi encontrada referência a um anel com escaravelho rotativo (63), achado na necrópole da Favela Nova, em Ourique, no túmulo 2, indicado como pertencente à colecção Luís Coelho.

\subsection{Objectos ainda em estudo}

Recentemente tomámos conhecimento de um novo acervo egípcio existente no nosso país, no Museu Ibérico de Arqueologia e Arte de Abrantes, que está em fase de organização. Prevê-se a construção de um novo edifício museal, mas enquanto tal não acontece as muitas e heterogéneas peças da colecção Estrada, a que se juntam outras reunidas pela edilidade abrantina, estão parcialmente em exposição na igreja de Nossa Senhora do Castelo (Panteão dos Almeidas). Entre os 
objectos expostos figuram seis de origem egípcia, sendo um deles um escaravelho(52).

64 - Escaravelho aparentemente do Império Novo (séculos XV-XII a. C.), com os clípeos razoavelmente assinalados, tendo na carapaça o protórax e os élitros bem marcados por incisões. De lado observam-se as patas em ligeiro relevo. A base ovalada apresenta-se com uma inscrição de aspecto fruste, parecendo ser uma ave.

Para além deste exemplar em exposição, o acervo reúne outros escaravelhos de tipologia variada que estão em fase de estudo e preparação para posterior publicação. Deles far-se-á aqui uma descrição sumária:

65 - Escaravelho aparentemente do período dos hicsos ou da fase inicial do Império Novo (século VXI a. C.), com clípeos e mostrando na carapaça o protórax e os élitros. Tem patas marcadas lateralmente e a base ovalada mostra um tipo de decoração esquemática que é comum em escaravelhos do período hicso.

66 - Escaravelho em mau estado de conservação, de difícil datação, com os detalhes anatómicos bastante erodidos, mal se distinguindo os clípeos e as linhas separadoras do protórax e élitros, com patas em relevo lateral. $\mathrm{Na}$ base tem alguns signos, entre os quais se distinguem o taui (Duas Terras), um escaravelho e outro que parece ser o símbolo do Oriente.

A colecção inclui uma pulseira de ouro de montagem moderna (século $\mathrm{XX}$ ) com sete escaravelhos de perfuração longitudinal, envolvidos por aros de ouro perlados e separados entre si por discos duplos, tendo os dois exemplares das extremidades um sistema de encaixe:

67 - Escaravelho com os clípeos razoavelmente assinalados, protórax separado dos élitros por um traço inciso e com as patas em relevo lateral.

68 - Escaravelho com os clípeos sumariamente assinalados, com a separação entre o protórax e os élitros já desaparecida, e com as patas em relevo lateral erodidas. $\mathrm{Na}$ base tem uma cartela com o nome Menkheperré ladeado por duas plumas e encimado por um udjat estilizado.

69 - Escaravelho com os clípeos esquematizados, protórax diminuto e separado dos élitros por um traço inciso, e com as patas em relevo lateral. $\mathrm{Na}$ base tem uma figura humana ladeada por símbolos que não se consegue identificar.

70 - Escaravelho com os clípeos muito erodidos, protórax separado dos élitros por um traço inciso, e com as patas em relevo lateral. 
corpo do escaravelho é ladeado por uma orla com incisões radiantes. Na base vê-se uma acumulação de signos que não dão qualquer leitura coerente, parecendo tratar-se de uma adaptação fruste da conhecida forma onomástica composta de Setepenré-meriamon, comum a vários reis do Império Novo e do Terceiro Período Intermediário.

71 - Escaravelho com os clípeos muito erodidos, protórax separado dos élitros por um traço inciso, e com as patas em relevo lateral. $\mathrm{Na}$ base tem uma decoração esquematizada com toscos signos, entre os quais um escaravelho ladeado por coroas vermelhas do Baixo Egipto.

72 - Escaravelho muito erodido, mal se notando os clípeos e os traços separadores do protórax e élitros. Na base tem três figuras humanas desajeitadamente gravadas, caminhando para a direita.

73 - Escaravelho com os clípeos esquematizados, protórax separado dos élitros por um traço inciso, com uma falha na superfície situada na terminação dos élitros, e com as patas em relevo lateral. $\mathrm{Na}$ base exibe vários símbolos geométricos.

Existe ainda um colar, também em montagem moderna, com onze escaravelhos de perfuração longitudinal, unidos entre si por um fio branco entretecido, com duas contas pretas em cada extremidade:

74 - Escaravelho com os clípeos assinalados de forma estilizazada, o protórax e os élitros separados por traços incisos, vendo-se ainda, em relevo esbatido, as patas laterais. A base está delimitada por uma orla incisa com uma figura humana de pé virada à direita tendo à frente a serpente sagrada iaret e em cima o que parece ser uma coroa vermelha do Baixo Egipto.

75 - Escaravelho com clípeos assinalados de forma estilizada, com o protórax e os élitros separados por traços incisos, e as patas em relevo lateral já erodido. $\mathrm{Na}$ base tem animais em marcha voltados à direita.

76 - Escaravelho muito erodido, não se vendo os clípeos, sem distinção da anatomia superior e mal se distinguindo as patas laterais. A base está delimitada por uma orla incisa com uma figura humana virada à direita exibindo um ceptro uase, ladeado por elementos decorativos inexpressivos.

77 - Escaravelho com os clípeos esquematizados, estando o protórax e os élitros separados por um traço duplo inciso, mal se distinguindo as patas laterais. Na base tem duas aves, com a mais pequena em cima, faltando já parte do objecto à frente.

78 - Escaravelho com os clípeos esquematizados, com o protórax e os élitros separados por uma incisão bem marcada, e com patas 
em relevo lateral. $\mathrm{Na}$ base tem uma figura humana de pé, virada à direita, e com um escaravelho à sua frente.

79 - Escaravelho muito erodido, com os clípeos indefinidos, mal se distinguindo os elementos anatómicos característicos, e com as patas laterais indefinidas. $\mathrm{Na}$ base tem dois signos men em oposição e outro não identificado.

80 - Escaravelho com os clípeos esquematizados, o protórax separado dos élitros por um traço inciso, e com as patas em relevo lateral. A base está envolvida por uma orla incisa e tem figuras humanas e de animais que não se conseguem identificar.

81 - Escaravelho com a cobertura parcialmente desaparecida, vendo-se os clípeos esquematizados, o protórax separado dos élitros por um traço inciso e os élitros separados entre si por um duplo traço inciso, com as patas em relevo lateral. $\mathrm{Na}$ base, envolvida por uma orla incisa, tem duas serpentes sagradas iaret cujas caudas caem para envolver um escaravelho feito com bons detalhes anatómicos.

82 - Escaravelho com os clípeos esquematizados, o protórax separado dos élitros por um traço inciso já esbatido e com as patas em relevo lateral. A base mostra uma figura humana virada à direita que segura nas mãos erguidas animais que não se consegue identificar.

83 - Escaravelho com os clípeos esquematizados, protórax com um buraco, separado dos élitros por um traço inciso, com os élitros separados entre si por um duplo traço inciso, e com as patas em relevo lateral. A base está delimitada por uma orla incisa e tem um cavalo em posição de marcha virado à direita, decorado com incisões no corpo e com signos hieroglíficos em cima.

84 - Escaravelho cujos detalhes anatómicos foram feitos com algum cuidado, notando-se razoavelmente os clípeos, o protórax e os élitros separados por um traço inciso, sendo a diferenciação dos élitros feita por dois traços incisos, e as patas em relevo lateral. $\mathrm{Na}$ base, envolvida por uma orla incisa, tem uma faixa central onde se lê a frase "Ptah é belo" (Ptah nefer), com a decoração superior feita por traços verticais incisos e a inferior com o signo neb.

\section{Conclusão}

Feita a análise breve dos escaravelhos egípcios ou egipcizantes que foi possível referenciar em Portugal, não deixa de ser surpreendente o número de exemplares até agora conhecidos: 84. No entanto, trata-se de um número susceptível de alteração, por novas informações 
que possam surgir a qualquer altura, até porque existem certamente pequenos acervos egípcios cujos proprietários ainda não acharam por bem divulgá-los, e porque as escavações na região do Alentejo e Estremadura prosseguem - e é lá que têm sido achados mais exemplares. Do total de escaravelhos conhecidos no nosso país, quatro exemplares são, como já vimos, escaravelhos do coração, outros quatro são escaravelhos alados e dois são do tipo escarabóide.

Em termos de materiais utilizados na sua feitura, um número considerável, de no mínimo 23 , na medida em que não temos informação sobre os materiais de todos os objectos referenciados, é feito de faiança, que, tradicionalmente, era o material mais em conta do ponto de vista económico e técnico.

Já no que respeita à datação dos objectos, encontramos um número importante de escaravelhos com datação segura ou proposta para o Império Novo ou posterior (séculos XVI-VIII a. C.) - cerca de um terço.

Em termos de divindades representadas, uma referência para Amon, que surge também na forma sincrética de Amon-Ré, estando esta importante divindade de Tebas-Uaset (mas venerada em todo o território) patente em três escaravelhos, bem como para a presença dos deuses Hórus e Heh e para a deusa Taueret, entre outras divindades não passíveis, por agora, de uma mais segura confirmação, como Sekhmet, Sobek ou Set.

No que respeita a nomes reais inscritos na base dos escaraveIhos, sublinhe-se a presença do prenome de Tutmés III (Menkheperré), em nove exemplares, bem como a de Psametek I (com o seu nome de Hórus), Padibastet e o prenome de Amen-hotep III (Nebmaetré).

Referência igualmente para o número de escaravelhos encontrados em trabalhos arqueológicos realizados no território português: dezassete - sendo que cinco deles são apontados como de possível produção de Náucratis ${ }^{(53)}$.

Verifica-se assim que em Portugal, entre os mais de mil objectos egípcios até agora estudados, existe um conjunto importante e diversificado de um dos símbolos mais representativos da cultura egípcia. Muito embora nem todos os escaravelhos aqui mencionados estejam expostos ao público, é possível, no entanto, apreciar estes típicos objectos de referência em vários museus do País, em vitrinas ou guardados nas reservas, constituindo uma janela aberta e muito instrutiva para a civilização do antigo Egipto e para os temas relacionados com a preparação para a viagem rumo à eternidade e à ressurreição. 


\section{Notas}

(1) ARAÚJO, Antiguidades Egípcias, I, p. 273.

(2) O Sol era associado de forma geral ao deus Ré. No entanto, as suas várias fases podiam ser associadas a outras divindades, nomeadamente a Khepri, representando o Sol matinal, a Ré-Horakhti, o Sol do meio-dia, e a Atum, o Sol do entardecer. Sobre o deus Khepri ver SALES, As Divindades Egípcias, pp. 104-106.

(3) PLUTARCO, Isís e Osíris, 381A: "Os escaravelhos, diz-se, são uma espécie sem fêmeas: sendo todos machos, colocam a sua semente numa bola de matéria que formam e fazem rolar empurrando com as suas patas traseiras, da mesma forma que o Sol, aparentemente, faz rodar o céu no sentido inverso ao do seu próprio curso, de oeste para este.”

(4) BEN-TOR, The Scarab. A Reflection of Ancient Egypt, p. 10. No que respeita aos escaravelhos com títulos e nomes de funcionários inscritos na base, datam em regra, segundo a autora, do Império Médio e do Segundo Período Intermediário (séculos XX-XVI a. C.), servindo uns como selos, outros como amuletos (p. 26).

(5) Para exemplos de escaravelhos do período hicso ver NEWBERRY, Ancient Egyptian Scarabs, plates XXI-XXV.

(6) Para exemplos de escaravelhos com inscrição de nomes reais ver TEETER, Scarabs, Scaraboids, Seals, and Seal Impressions from Medinet Habu, pp. 27-47.

(7) Desde o Império Antigo a titulatura real integrava o nome de Hórus, o nome de Nebti (ou nome das Duas Senhoras, as deusas Nekhbet e Uadjit), o nome de Hórus de Ouro, o prenome e por último o nome, sendo estes dois últimos reais nomes inscritos dentro de cartelas.

(8) Ver exemplos de escaravelhos com inscrição de nomes de divindades em TEETER, Scarabs, Scaraboids, Seals, and Seal Impressions from Medinet Habu, pp. 47-57.

(9) BEN-TOR, The Scarab. A Reflection of Ancient Egypt, pp. 34-38.

(10) COONEY \& TYRRELL, Scarabs in the LACMA, p. 7; ver também NEWBERRY, Ancient Egyptian Scarabs, plates XXXIV-XXXVI.

(11) Período histórico que decorreu entre 664-525 a. C., correspondendo à XXVI dinastia.

(12) Para exemplos de escaravelhos do coração com inscrição ver TEETER, Scarabs, Scaraboids, Seals, and Seal Impressions from Medinet Habu, pp. 124-132.

(13) Veja-se, entre outros exemplos, o caso de um escaravelho do coração, pertencente à colecção egípcia do Metropolitan Museum of Art de Nova lorque, feito de pórfiro verde, medindo $8 \mathrm{~cm}$ de comprimento, $5,7 \mathrm{~cm}$ de largura e apenas $1,6 \mathrm{~cm}$ de espessura, que pertenceu a Amenirdis I, adoradora divina em Tebas e irmã de Pié, rei da XXV dinastia (ver C. L. R., "Heart Scarab of Queen Amenardis", p. 116).

(14) Para a deusa Maet e o elevado conceito humanista de maet veja-se ARAÚJO, "Maet", Dicionário do Antigo Egipto, pp. 524-536.

(15) Depois de o defunto ser declarado justificado no tribunal de Osíris considerava-se osirificado para fruir da vida eterna, pelo que se seguia ao seu nome a expressão de maé-kheru, isto é, "justo de voz". Como exemplo de um texto com o capítulo 30 do "Livro dos Mortos" veja-se a versão gravada num exemplar da colecção Sam Levy em ARAÚJO, "Um escaravelho do coração numa colecção privada portuguesa", pp. 7-27.

(16) Ibidem. 
(17) Esta situação detecta-se também nos exórdios dos textos das estatuetas funerárias, com o capítulo 6 do "Livro dos Mortos". No entanto, enquanto nas estatuetas funerárias o título-nome de Osíris (Usir) vem, regra geral, antecedido pela fórmula sehedj ("Que brilhe"), tal não se verifica nos textos do capítulo 30 presentes nos escaravelhos.

(18) Para o reinado de Amen-hotep III (1390-1353 a. C.), considerado por vários egiptólogos como sendo o momento de maior apogeu da civilização faraónica, ver ARAÚJO, "Amenhotep III", em Dicionário do Antigo Egipto, pp. 59-60.

(19) Sobre a rainha Tié, esposa de Amen-hotep III, veja-se ARAÚJO, "Tié», em Dicionário do Antigo Egipto, p. 824.

(20) Ver exemplos em NEWBERRY, Ancient Egyptian Scarabs, plates XXXII-XXXIII; cf. LANSING, "A Commemorative Scarab of Amen-hotep III", pp. 12-14.

(21) Cf. LANSING, "A Commemorative Scarab of Amen-hotep III", pp. 12-14.

(22) Ibidem.

(23) ARAÚJO, Antiguidades Egípcias, I, pp. 273-275.

(24) HOWORTH, "Egypt or Phoenicia at Mykaenae, etc.", p. 78.

(25) BEN-TOR, The Scarab. A Reflection of Ancient Egypt, p. 8.

(26) Cf. ARAÚjo, O Núcleo Egípcio da Colecção Marciano Azuaga, pp. 12-15.

(27) O motivo da barca solar continuaria a estar presente nas bases de escaravelhos produzidos em épocas muito tardias e serviria mesmo de inspiração para a produção de escaravelhos pseudo-egípcios ou de tipo egipcizante aparecidos em vários pontos do Mediterrâneo, nomeadamente em Ibiza e em Cartago (cf. ARAÚJO, O Núcleo Egípcio da Colecção Marciano Azuaga, p. 25, nota 11).

(28) Cf. ARAÚJO e LOPES, “A colecção egípcia do rei D. Luís", pp. 17-28.

(29) Cf. COSTA, "O tesouro púnico-tartéssico do Gaio, Sines (séc. VII a. C.). Novos achados", pp. 14-15. Agradecemos ao Dr. Rui Santos, do Museu Arqueológico de Sines, a disponibilização de fotografias e de informação sobre o objecto. De acordo com o egiptólogo inglês Rowland, consultado pelo arqueólogo José Miguel da Costa, a cujo texto sobre a peça em causa tivemos acesso, o escaravelho seria recente e provavelmente feito na Fenícia, e não no Egipto. Acrescenta ainda que a cartela é original mas será duvidoso que seja datada do reinado de Tutmés III, pois o prenome deste famoso monarca continuou a ser copiado nos escaravelhos por muito tempo após a sua morte em 1425 a. C.)

(30) ARAÚJO, Arte Egípcia, pp. 104-105 e p. 160.

(31) Cf. ARAÚJO, "A colecção egípcia do Museu Condes de Castro Guimarães", pp. 12-15. A colecção integra ainda alguns objectos egipcizantes, mas do domínio da egiptomania, destacando-se aqui um escaravelho feito em pedra leve com um tom verde claro. Apresenta de forma razoável a anatomia do escaravelho e na base tem inscrito o nome real encartelado de Nebmaetré (prenome do faraó Amen-hotep III) ladeado por plumas. Data provavelmente do século XIX e tem as seguintes dimensões: comp.: $7,9 \mathrm{~cm}$; larg.: $5,6 \mathrm{~cm}$; alt: $4 \mathrm{~cm}$.

(32) Agradece-se à Dra. Paula Basso, curadora do Museu da Farmácia, a disponibilização de fotografias e de informação suplementar sobre os objectos, embora neste artigo elas não possam ser inseridas por falta de espaço. Ver BASSO e ARAÚJO, A Farmácia no Mundo Pré-clássico e nas Culturas Tradicionais, 2008. 
(33) GAMER-WALLERT e PAIXÃO, «A inscrição do escaravelho de Psamético I, da necrópole do Olival do Senhor dos Mártires, elementos para a sua interpretação", p. 272.

(34) Em Ägyptische und ägyptisierend Funde von der iberischen Halbinsel, p. 120. Ingrid Gamer-Wallert assinala ainda na sua monografia um pequeno escaravelho encontrado em Odemira. No entanto, contactada a Câmara Municipal de Odemira, fomos informados que desconhecem a existência de um escaravelho encontrado em Odemira. A técnica responsável, Dra. Ana Tendeiro, informou que as peças encontradas na zona até 2000 foram enviadas para o Museu Nacional de Arqueologia ou para o Museu Regional de Beja. As descobertas arqueológicas feitas posteriormente a 2000 têm sido encaminhadas para a Estação Arqueológica da Necrópole do Pardieiro. Ana Tendeiro deu-nos ainda conta que tiveram lugar duas escavações na zona durante os anos 80 , uma conduzida por Caetano de Mello Beirão, e uma outra por José Morais Arnaud (concelho de Fiais). Contactámos ainda, no mesmo sentido, com o conservador do Museu Regional de Beja, Dr. José Carlos de Almeida Oliveira, que nos informou que a colecção do Museu não integra qualquer escaravelho (inventário feito por Abel Viana).

(35) Estes dois objectos foram estudados por Maria Amélia Horta Pereira, tendo sido publicados na revista Conimbriga, vol. XIV, do Instituto de Arqueologia da Universidade de Coimbra, 1975, pp. 173-175. Agradece-se ao Dr. Filipe Soares Rogeiro, do Museu Hipólito Cabaço, a disponibilização das fotografias dos objectos, que neste artigo, por motivos de espaço, não serão incluídas.

(36) De acordo com a arqueóloga Maria Amélia Horta Pereira, que estudou o objecto, a voluta exageradamente grande nas pálpebras inferiores dos udjat indicaria tratar-se de uma interpretação oriental, e a ausência de traço horizontal na base da cartela mostra que será possivelmente uma cópia fenícia. Acrescente-se que no prenome do rei (Menkheperré) foi acrescentado o hieróglifo unilítero $r$, ortografia neo-egípcia de kheper.

(37) Para a opinião de Ingrid Gamer-Walert veja-se Ägyptische und ägyptisierend Funde von der iberischen Halbinsel, p. 120.

(38) ARAÚJO, Antiguidades Egípcias, I, p. 276. Ver também CUNHA e SOUSA, "A Colecção de Antiguidades Egípcias do Museu de História Natural da Universidade do Porto", pp. 235-241.

(39) DEUS e CORREIA, “Corte Margarida. Mais uma necrópole orientalizante no Baixo Alentejo", pp. 615-618. Agradece-se à arqueóloga Manuela de Deus a disponibilização de informação e de fotografias do objecto, embora estas não se incluam no presente artigo.

(40) Agradece-se ao arqueólogo Luís Barros, do Museu Municipal de Almada, a disponibilização de úteis informações sobre o objecto, já integradas na sua dissertação de mestrado sobre O Fim do Bronze e a ldade do Ferro no Território de Almada.

(41) Para a descrição dos escaravelhos do Museu Nacional de Arqueologia ver ARAÚJO, Antiguidades Egípcias, I, pp. 273-287. Agradece-se à Dra Maria José Albuquerque, do MNA, a disponibilização das fotografias dos objectos e as facilidades concedidas no seu estudo.

(42) Para mais informação sobre os escaravelhos n. ${ }^{\circ 5} 45,46$ e 47 ver PAIXÃO, "O recente achado de três escaravelhos na necrópole do Senhor dos Mártires em Alcácer do Sal», pp. 312-313.

(43) Ver PAIXÃO, "Necrópole proto-histórica do Senhor dos Mártires (Alcácer do Sal)", p. 283.

(44) Para maior informação sobre este escaravelho ver ARAÚJO, “A Colecção Egípcia do Museu Nacional de Soares dos Reis", pp. 7-11.

${ }^{(45)}$ Cf. ARAÚJO, "O Núcleo Egípcio da Colecção Fernando Freitas Simões”, pp. 21-22. 
(46) O objecto foi oferecido a Luís Manuel de Araújo pelo coleccionador Sam Levy, e esteve exposto no Museu Arqueológico de Odrinhas por ocasião da mostra sobre "O embalsamamento egípcio", feita como homenagem a Rómulo de Carvalho (Setembro de 2007 a Março de 2008).

(47) Ver ARAÚJO, "Novos objectos egípcios em colecções privadas de Portugal», pp. 206-207. Agradece-se ao Doutor Mário Jorge Barroca as informações prestadas a e disponibilização de fotografias do objecto.

(48) Cf. ARAÚJO, "O Núcleo Egípcio da Colecção Sam Levy", pp. 42-46. Para a tradução da inscrição hieroglífica ver pp. 43-44.

(49) Agradece-se ao arqueólogo Filipe Santos a disponibilização de informações e as fotografias do objecto.

(50) Ver DIAS, BEIRĀO e COELHO, «Duas Necrópoles da Idade do Ferro no Baixo-Alentejo: Ourique", pp. 181-182, e ainda BEIRÃO e GOMES, A I Idade do Ferro no Sul de Portugal. Epigrafia e Cultura, p. 18.

(51) Em Ägyptische und ägyptisierend Funde von der iberischen Halbinsel, p. 120.

(52) Ver ARAÚJO, "Antigo Egipto", Museu Ibérico de Arqueologia e Arte de Abrantes, pp. 69-73. Agradece-se ao Professor Fernando António Baptista Pereira e ao Dr. Gustavo Portocarrero as facilidades concedidas para o estudo das peças da colecção Estrada.

(53) Para a importância de Náucratis, activo entreposto comercial greco-egípcio no Delta Ocidental, ver RODRIGUES, “Náucratis», Dicionário do Antigo Egipto, pp. 602-603.

\section{Bibliografia consultada}

Cyril ALDRED, The Egyptians, Col. Ancient Peoples and Places, Londres: Thames and Hudson, 1984

Luís Manuel de ARAúJO, Antiguidades Egípcias, I, Museu Nacional de Arqueologia, Lisboa: Instituto Português de Museus, 1993

— "A colecção egípcia do Museu Nacional Soares dos Reis", em Museu, 3, IV série, Porto: Museu Nacional Soares dos Reis, 1995, pp. 7-11

- O núcleo egípcio da colecção Marciano Azuaga, Câmara Municipal de Vila Nova de Gaia, Sector de Acção Cultural, Casa Municipal de Cultura, Solar Condes de Resende, Vila Nova de Gaia, 1995

— "O núcleo egípcio da colecção Fernando Freitas Simões", em Clio, 4, Lisboa: Centro de História da Universidade de Lisboa, 1999

— "Um escaravelho do coração numa colecção privada portuguesa", em Museu, 9, IV, Porto: Museu Nacional de Soares dos Reis, 2000, pp. 7-27

— "Amuletos", Dicionário do Antigo Egipto, Lisboa: Editorial Caminho, 2001, pp. 66-67

— “Escaravelho», Dicionário do Antigo Egipto, Lisboa: Editorial Caminho, 2001, pp. 329-331

— «Maet», Dicionário do Antigo Egipto, Lisboa: Editorial Caminho, 2001, pp. 524-536

- "O núcleo egípcio da colecção Sam Levy", em Artis, 1, Lisboa: Instituto de História da Arte da Faculdade de Letras da Universidade de Lisboa, 2002, pp. 31-56

- "A colecção egípcia do Museu Condes de Castro Guimarães", em Arquivo de Cascais, 13, Cascais: Câmara Municipal de Cascais, 2005, pp. 11-22

— "Novos objectos egípcios em colecções privadas de Portugal», em Cadmo, 15, Lisboa: Instituto Oriental da Universidade de Lisboa, 2005, pp. 203-207

— Arte Egípcia, Colecção Calouste Gulbenkian, Lisboa: Museu Calouste Gulbenkian, 2006 
"Antigo Egipto", Museu Ibérico de Arqueologia e Arte de Abrantes, Abrantes: Câmara Municipal de Abrantes, 2009, pp. 66-73

Luís Manuel de ARAÚJO e Maria Helena Trindade LOPES, "A colecção egípcia do rei D. Luís", em Hathor. Estudos de Egiptologia, 4, Lisboa: Edições Cosmos, 1992, pp. $17-28$

John BAINES e Jaromír MÁLEK, Atlas of Ancient Egypt, Oxford: Phaidon Press, 1981

Lorenzo BAQUÉS, «Improntas de diez escarabeos egipcios de supuesta procedencia ibicenca", em Ampurias, vol. 41-42, Barcelona: Museu d'Arqueologia de Catalunya, 1979-80, pp. 377-390

Lorenzo BAQUÉS, "The foundation date of Ibiza from the Egyptian scarabs found there", em Acts 1st International Congress of Egyptology, Cairo: 1976, pp. 87-94, Tafel III-IV

Lorenzo BAQUÉS ESTAPÉ, Escarabeos egipcios de Ibiza, Monografías, XLVII, Barcelona: Diputación Provincial de Barcelona, Instituto de Prehistoria y Arqueología, 1974-75

Paul BARGUET, Le Livre des Morts des Anciens Égyptiens, Col. Littératures Anciennes du Proche-Orient, 1, Paris: Les Éditions du Cerf, 1968

Paula BASSO e Luis Manuel de ARAÚJO, A Farmácia no Mundo Pré-clássico e nas Culturas Tradicionais, Lisboa: Associação Nacional das Farmácias, Museu da Farmácia, 2008

Caetano de Mello BEIRÃO e Mário Varela GOMES, A I Idade do Ferro no Sul de Portugal. Epigrafia e Cultura, Lisboa: Museu Nacional de Arqueologia e Etnologia, 1980

Daphna BEN-TOR, The Scarab. A Reflection of Ancient Egypt, Jerusalém: The Israel Museum, 1979

COONEY \& TYRRELL, Scarabs in the Los Angeles County Museum of Art, Part I, em www.PalArch.nl, Archaeology of Egypt/Egyptology, 4, 1 (2005)

José Miguel da COSTA, "O Tesouro Púnico-Tartéssico do Gaio, Sines (séc. VII a. C.). Novos achados", Actas das II Jornadas Arqueológicas, vol. III, Lisboa: Associação dos Arqueólogos Portugueses, 1974

Maria José CUNHA e Rogério Ferreira de SOUSA, «A Colecção de Antiguidades Egípcias do Museu de História Natural da Universidade do Porto", em Revista da Faculdade de Letras. História, III série, 7, Porto: Faculdade de Letras da Universidade do Porto, 2006, pp. 235-241

François DAUMAS, La Civilisation de l'Egypte Pharaonique, Paris: Arthaud 1965

Manuela de DEUS e José CORREIA, "Corte Margarida. Mais uma necrópole orientalizante no Baixo Alentejo", em Actas del III Simposio Internacional de Arqueología de Mérida: Protohistoria del Mediterráneo Occidental, Mérida: Instituto de Arqueología, 2005

Maria Manuela Alves DIAS, Caetano de Melo BEIRÃO e Luís COELHO, "Duas Necrópoles da Idade do Ferro no Baixo-Alentejo: Ourique", em O Arqueólogo Português, III, vol. 4, Lisboa: Museu Nacional de Arqueologia e Etnologia, 1970

Raymond O. FAULKNER, A Concise Dictionary of Middle Egyptian, Oxford: Oxford University Press, 1984

Ingrid GAMER-WALLERT, Ägyptische und ägyptisierende Funde von der Iberischen Halbinsel, Beihefte zum Tübinger Atlas des Vorderen Orients, 21, Wiesbaden: Dr. Ludwig Reichert Verlag, 1978 
Ingrid GAMER-WALLERT e António CAVALEIRO PAIXÃO, "A inscrição do escaravelho de Psamético I, da necrópole do Olival do Senhor dos Mártires, elementos para a sua interpretação", em O Arqueólogo Português, IV, 1, Lisboa: Museu Nacional de Arqueologia e Etnologia, 1983, pp. 267-272

Alan GARDINER, Egyptian Grammar, being an Introduction to the Study of Hieroglyphs, 3. ${ }^{a}$ ed. revista, Griffith Institute, Ashmolean Museum, Oxford: Oxford University Press, 1957

Charles R. GILLETT, "The Ward Collection of Egyptian Scarabs", em The Metropolitan Museum of Art Bulletin, The Metropolitan Museum of Art, vol. 1, n..$^{\circ}$. Nova lorque (Jan., 1906), pp. 43-45

Nicholas GRIMAL, Histoire de l'Égypte ancienne, Paris: Librairie Arthème Fayard, 1988

Erik HORNUNG, History of Ancient Egypt, Edimburgo: Edinburgh University Press, 1999

Maria Amélia HORTA PEREIRA, "Objectos egípcios do Porto do Sabugueiro (Muge)», Conimbriga, vol. XIV, Coimbra: Instituto de Arqueologia da Universidade de Coimbra, 1975 , pp. 173 a 175

Henny H. HOWORTH, "Egypt or Phoenicia at Mykaenae, etc.", em The Classical Review, The Classical Association, vol. 7, n. $^{\circ} 1 / 2$, (Fev. 1893). p. 78

Ambrose LANSING, "A Commemorative Scarab of Amen-hotep III», em The Metropolitan Museum of Art Bulletin, The Metropolitan Museum of Art, vol. 31, n. ${ }^{\circ}$ 1, Nova lorque, (Jan., 1936), pp. 12-14

Percy E. NEWBERRY, Ancient Egyptian Scarabs. An Introduction to Egyptian Seals and Signet Rings, Chicago: Ares Publisher Inc., 1979

Josep PADRÓ, "Península Ibérica», em Dicionário do Antigo Egipto, Lisboa: Editorial Caminho, 2001, pp. 670-673

António Cavaleiro PAIXÃO, «Necrópole proto-histórica do Senhor dos Mártires (Alcácer do Sal)", em O Arqueólogo Português, IV, 1, Lisboa: Museu Nacional de Arqueologia e Etnologia, 1983, pp. 275-283

António Cavaleiro PAIXÃO, "O recente achado de três escaravelhos na necrópole do Senhor dos Mártires em Alcácer do Sal", em Actas do II Congresso de Arqueologia, Coimbra: Junta Nacional de Educação, 1970, pp. 309-314

PLUTARCO, Isis e Osíris: os mistérios da iniciação, Lisboa: Fim de Século, 2001

Nuno Simões RODRIGUES, “Náucratis», Dicionário do Antigo Egipto, Lisboa: Editorial Caminho, 2001, pp. 602-603

José das Candeias SALES, As Divindades Egípcias, Lisboa: Editorial Estampa, 1999

Rogério Ferreira de SOUSA, "Coração", em Dicionário do Antigo Egipto, Lisboa: Editorial Caminho, 2001, pp. 234-236

Emily TEETER, Scarabs, Scaraboids, Seals, and Seal Impressions from Medinet Habu, The Oriental Institute of the University of Chicago, vol. 118, Chicago: The University of Chicago Press, 2003

Jean VERCOUTTER, Les objets égyptiens et égyptisants du mobilier funéraire carthaginois, Paris: P. Geuthner, 1945

Jean YOYOTTE, "Scarabée", em George Posener (dir.), Dictionnaire de la Civilisation Égyptienne, Paris: Fernand Hazan, 1970, pp. 259-260 